Boštjan Marko Turk

Univerza v Ljubljani

Filozofska fakulteta

bostjan-marko.turk@guest.arnes.si
UDK 82.09-1=112.2Prešeren F.:82.09-1Ovidius Naso P. DOI: $10.4312 /$ vestnik.7.37-49

\title{
NIZ PREŠERNOVIH JEZIKOV
}

Nemški del opusa Franceta Prešerna je že bil ustrezno evidentiran, kar pa še ne pomeni, da v sto sedeminsedemdesetih letih, ${ }^{1}$ odkar se v zamenjujočih obrazih pojavlja v obzorju literarne znanosti, njegova mise en évidence ni doživela ustrezne diferenciacije. Izstopajoča dilema je, čemu je pesniku služila pesem, čemu sedaj v slovenski, sedaj v nemški komponenti, osmišljena pa spet latinsko, kakor je intoniral Nameček nemških in ponemčenih poezij (Prešeren: 1965, 68). Kakšen je tu prostor literarne eksegeze? Zmedo vnese že pogled na očitno razstavljanje v delce tistega, kar naj bi pomenilo skupno izhodišče narodnostno-jezikovne definicije Prešernove pesmi.

Najočitnejša predrefleksivna usedlina sega v čas samega odkritja njene tehtnosti za slovensko skupnost. Gre za Stritarjev uvod v izdajo Poezij (Stritar: 1955, 46) v katerem je prvič najti formulacije o tem, da vsak narod v najvišjem zapopadku slavi nekoga, ki mu pridaja avreolo umetelne svetosti. Josip Stritar je v tem razmišljanju postavil paralelo med evropsko klasično poezijo Williama Shakespeara, Jeana Racina, Danteja Aligerija, Johanna Wolfganga von Goetheja, Aleksandra Sergejeviča Puškina in Adama Mickiewicza na eni ter Franceta Prešerna na drugi strani, izhajajoč iz estetsko-nacionalnega momenta. Stritarjeva ocena je natančna, četudi je nastala le sedemnajst let po pesnikovi smrti, je čas ni ne popravil ne dopolnil.

Zalezla se je v narodno podzavest, kot tako jo je formuliral tudi Marc Alyn v svoji sintetični študiji, namenjeni predstavitvi pesnika francoskemu okolju. Tako pravi: »France Prešeren ni samo narodni pesnik par excellence, lahko rečemo, da se v očeh svojih rojakov istoveti s pojmom naroda samega« (Alyn: 1982, 8). Alynova študija, ki do te ugotovitve prihaja ob sintetični analizi kulturnega okolja v Prešernovem času, navaja Stritarjevo ugotovitev in ji pritrjuje. Vendar je ta ugotovitev, najsi se sliši še tako splošno, v bistvu sama fragment. Kajti na delce ${ }^{2}$ jo razstavi drug navedek, iz knjige Evropska literarna dediščina. Tam preberemo informativno poved: »France Prešeren, ki je slavljen kot največji slovenski pesnik, se je rodil v Vrbi, blizu romantičnega blejskega jezera, pod gorskimi grebeni Julijskih Alp in Karavank« (Polet: 1999, 184). To je sicer vsebinsko nesporno, sporna

\footnotetext{
1 Prvi, Vrazov prevod nemške pesmi v slovenščino je iz 1. 1837.

2 Beseda »delec« ima v pričujočem zapisu zelo natančen pomen. V neposrednem besedilu predvsem pa $\mathrm{v}$ navedenih prevodih predstavlja sinonim tujki »fragment«, v celoti oblikotvornih pomenov.
} 
pa je jezikovna rubrika, v katero se poglavje samo uvršča. Ta se imenuje »Prě̌eren: nemško-slovensko (področje) «(184). ${ }^{3}$

Element, ki slabi Prešernovo nacionalno identiteto, v tem smislu ni osamljen. Tako bodo pesnika klasificirali mnogi, tudi za potrebe univerzitetnega pedagoškega procesa v tujini. Skupni imenovalec takšne nedorečenosti bo zaključek, da je France Prešeren istoveten s slovenskim narodom in njegovo poezijo na način, na katerega je le-ta istoveten z nemškim narodom (in njegovo poezijo). Takšen nesmisel ukinja možnost razločevalnih kriterijev. Gradivo je bilo sicer evidentirano, celo glede na vsako od enot iz pesniškega izbora: glede na jezik, izvor in namen (nastanka). A prejkoslej ostaja vprašanje: kje je jedro, ki povezuje fragmente v logično celoto, predvsem v tisto, ki odgovarja na temeljno dilemo: iz katerega jezikovnega območja je pesnik prišel in kakšno je bilo medsebojno razmerje med jezikovnimi registri, ki jih je uporabljal?

Hipotetični odgovor že obstaja, in sicer kot del splošne zgodovinske vednosti. Kultura slovenskega prostora v začetku devetnajstega stoletja je bila namreč nemška. »Pred dvesto leti je bila slovenščina kot zahodnoslovansko »narečje« pokrajinski jezik pastirjev, rokodelcev in kmetov« (Moder: 1995, 78). Zasebno življenje je potekalo v slovenskem jeziku, a uradno se je odvijalo v nemščini. V njej so poslovali trgovci, sodišča, pisarne. Slovenščina je bila od opolnomočenega jezika tako ločena v dveh, bistvenih segmentih. Prvi je pomenil njeno nezadostnost glede na ustvarjalnost, kompetenco in prestiž družbenega sloja samega. Jezik, naravnan na párije, je tako ostajal zunaj tistih plasti družbe, ki so bile reproduktivne. In druga, še težja pohabljenost: slovenščina je bila fizično ločena od jezikovnih funkcij, ki bi jo vzpostavile v njeni reprezentativni vlogi. Gre za namembnost, ki sama spričo prakse določenih jezikovnih registrov izpolnjuje v konkretnem času in prostoru Saussurjevo namembnost onega orodja, ki smo ga pridobili s sposobnostjo integralnega sporazumevanja preko jezikovnih znakov (Saussure: 1998). A ta aparat je bistveni del človeka in predvsem besednega umetnika. V prvem približku ${ }^{4}$ je problem vsakogar, ki bi se lotil »demontaže« te socialne in vrednostne konstrukcije ontološkega značaja. Premaknil bi ga niti za ped. Da bi to razumeli celoviteje, navedimo realistično, večverzno poved:

\section{»Deutsch sprechen in der Regel hier zu Lande / \\ Die Herrinen und Herren, die befelen,/ \\ Slowenisch die, so von dem Dienerstande« (Prešeren: 1965, 81). ${ }^{5}$}

To sporočilo slovenski jezik umešča v horizont bivanjske izkušnje, v trpkem pomenu besede. Pesnikova ugotovitev se v pomembnem zoperstavlja romanticističnemu

\footnotetext{
3 Proti umeščanju Franceta Prešerna v nemško govorno področje je pri uredništvu, ki je delo izdajalo, protestiral Vladimir Boris Pogačnik, tedaj visokošolski učitelj na Inalcu v Parizu, a zaman.

4 Izraz »približek« je enakoznačen francosko literarnoteoretičnemu pojmu »approche«.

5 Citat prvič navajamo v izvirniku, kasneje v prevodu. Razloga sta dva: prvič, gre za največkrat navajano mesto, tako da njegova identifikacija ni problematična. Drugič: navajajo ga tudi drugi, v nemški obliki (Kidrič: 1978, 127).
} 
pojmovanju literarne vede iz njenih začetkov, namreč, da naj bi France Prešeren ne razlikoval docela med slovensko, kranjsko in slovansko entiteto. To bi posledično pomenilo, da so možnosti za ustvarjanje nečesa novega teoretično neskončne. In da je zategadelj konflikt manj živ in lagodneje občuten. Tako: »Prešeren je začel kot kranjski pesnik, a je nehaval kot slovenski. V svoji kranjski dobi je rabil obliko Slovenec za Slovane sploh, a ker mu je v drugi dobi služila tudi v ožjem, današnjem smislu, kako je pa tedaj imenoval Slovane? Pravega imena nima, ali našteva vrstna imena » (Ilešič: 1900, 18). Pesnik je razlikoval med stopnjami družbene, jezikovne in spolske hierarhije, pri čemer mu je izraz »slowenisch « ${ }^{6}$ zanesljivo odrejal mesto njegove etnije, njenih prebivalcev, moških v odnosu do žensk iz dominantnejšega jezikovega področja. Ni šlo za vrstno opredeljevanje, kot bi menili glede na neposredno naravo Ilešičeve formulacije, temveč je beseda o kvalitativni določitvi. Njen denotat predstavlja zavest o manjvrednosti, natančneje o odsostvujočem smislu potegovanja, naprezanja ali prizadevanja za nekaj, kar se označuje kot slovensko. Podobno formulacijo najdemo v elegiji, spisani dobro leto kasneje: »Na tleh leže slovenstva stebri stari, v domačih šegah vtrjene postave« (Prešeren: 1965, 179).

Gre za preliminarni del Črtomirove refleksije, ki se v koncentričnih krogih obupa čisto ponevedoma dotakne tudi tvorca samega:

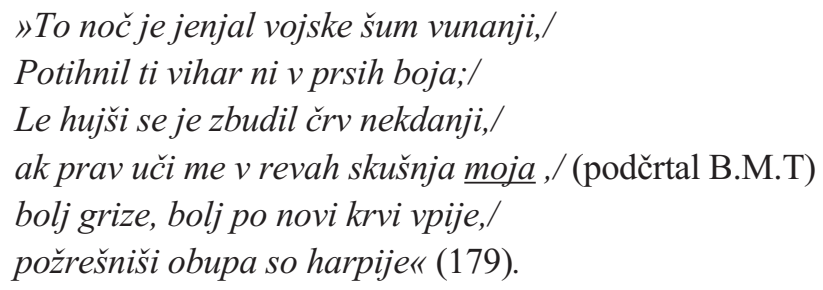

Ta poseg avtorja, bolje apóstrofa liričnemu subjektu, ni naključna. V njej je Prešeren povzel breme brezizhodne skušnje domovinske tedajšnjosti, kot se je njemu in junaku razodevala skozi lasten osebni fiasko. »Slovenstva stebri stari« in njihov kontemplator, prikrajšani staroslovenski princ, se v avtorju namreč na široko zrcalijo. Tako poraženi bojevnik kot brezupni pesnik se ne moreta slepomišiti: prostor njunega družbenega, erotičnega in dejavnega bitja ni Kranjska ali neka abstraktna, v hipotetično prihodnost odprta slovanska etnija. Nasprotno: to je Slovenija, geografsko sicer še ne do konca sklenjena, kulturno, jezikovno in politično pa obstoječa, zaključena, skozi vse mogoče poraze in zanikanja, od prvih bojev staroslovenskih prednikov do trenutka, ko jih aktualizira Prešernova misel. Takšna »Slovenija« je karseda vprašljiva.
»V najstrožji službi, ki ljudje svobodni /
so kdaj služili jo, v ljubezni ječi, /
ne smem grešiti proti šegi rodni« (Prešeren 1960, 81).

6 Navedena pesem je bila napisana leta 1834 . 
V dosledni razvezavi je zadnja tercina v »Zakaj nji, vredni« sporočilo o tem, da se poveličevanemu dekletu ne sme zapeti v drugem jeziku, kot je jezik »gospodi služečih«, to pa je tudi prepoved osmišljevanja poetične stvari in njene raznoplastnosti. Ukinitev smisla, v katerem se oseba pesnika, njene nacionalne ideje, predvsem pa njene »skladnje« vzpostavlja na dejanski, referenčni jezikovni funkciji. Zakaj bi o lepem, pomembnem, »vrednem« sploh pel v nelepem, nepomembnem in nevrednem mediju, oz. jeziku? Prestavimo pričujoči stavek v antitetično poved, pa se odkrije smisel dileme. Ali stvari, ki so opevane v jeziku, zunaj njega nimajo vrednosti, ali jezik sam ni vreden, da bi stvari kot take opeval.

Ta nič jezikovne reference je romantičen v smislu literarno-zgodovinske obvezujočnosti. Vendar zgolj v tem. Vselej je bilo dovolj romantikov, ki so si prizadevali za sklep Črtomirove dileme, ali nisem morda sam nevreden medij česarkoli ali vsega, kot je to na koncu spoznal Heinrich Von Kleist.
»Premagan pri Bohinjskem sam jezeri
Stoji naslonjen na svoj meč krvavi,
Z očmi globokih brezen valov meri,
Strašne mu misli rojijo po glavi,
Življenje misli vzet' si v slepi veri« (Prešeren: 1965, 183).

Prešernova točka, exitus in redditus, njegovega »zapisa« je tudi topografski temelj njegovega razmerja do jezika in jezikov. Ta bipolarna drža je romantična, tu v izhodišču se največji slovenski pesnik identificira kot nezamenljiv romantik. Zanj veljajo pričujoče formulacije:

"Zaostrena nervoza je brez dvoma v ospredju povečane zmožnosti trpljenja.Vergil, Pascal, Racine, Marivaux, vselej je bilo v nizu pesnikov dovolj tistih, ki so bili pretirano občutljivi ali pretirano ranljivi. Toda nikdar ni to doseglo takšne razsežnosti v številu obolelih duš ali na stežaj odprtih ran kot v romantiki. Romantiki so svoje mreže postavili previsoko. Tudi v umetnosti je njihov ideal izzvenel kot nedosegljiv, kajti njihova slabost, bodisi jezika bodisi njegove grafične oblike jih je vodila do obupa. Goethe se je temu še upiral, Schiller je umrl mlad, toda koliko drugih je v Nemčiji občutilo s tesnobo nezmožnost življenja v idealnem svetu sanj ter se je zateklo k samomoru. Če niso že poprej omagali v nevrasteniji! Hoelderlinu se je po njegovem tridesetem letu pomotilo v glavi. Heinrich von Kleist se je ubil skupaj s Henrieto Vogel. Prav tako mnogo drugih, začenši s Karolino Gunderodško« (Peyre: 1971, 120).

Vendar je Prešernova romantika, glede na nastavek, ki smo ga poskušali skicirati, drugotna. Prešernova romantika je aparat, s katerim je konkretni posameznik posegel v jezikovno materijo, predvsem pa v sociološko, hierarhično-eksistencialno danost, bolje bistvo. 
Romantika je exupéryjevsko orodje za dvig nad to, česar nikomur ni uspelo preseči, slovenstva oz. slovenskega duha, v obvezujočem razmerju do sosedov, kot kvalifikacijske norme in družbenega postulata. Ne smisel sam, temveč orodje. Prešernova romantika je redukcija Peyrejeve definicije in njenih členov na bivanjsko točko nič prividne ali shizofrene sociolingvistične izkušnje, eksistencialno formulirane v prav vsakem od zgornjih pesnikovih verzov. Ker je ničta točka kot počelo bivajoče resničnosti tvorca natančen korelat romantike in njenih derivatov, prav do zadnje skrajnosti, do niča smrti in besede, sta obe plasti med seboj zrasli tako močno, lahko rečemo: Prešernov nič jezika in življenjske »cene « ${ }^{7}$ sta romantična v najbolj pregnantnem smislu besede. »Misel je absolutna sinteza absolutnih antitez, nepojenjujoče in samo sebe ustvarjajoče izmenjavanje protislovnih misli« (Schlegel: 2004, 299). Tako Friedrich von Schlegel.

$\mathrm{S}$ to mislijo se lahko približamo najbolj kontradiktornemu tovrstnemu signalu v Prešernovem delu, latinski intonaciji nemških in ponemčenih poezij, ki so bile sprva predvidene za objavo v Poezijah (Prešeren: 1847), a so kasneje iz neznanih razlogov ostale zunaj njih, četudi jih je avtor sam že razporedil tako, kot se mu je zdelo smiselno. Z bratoma Schlegel so še dodatno povezane. Upoštevati moramo, da sta prav na osnovi njunih tez Prešeren in Čop razvijala artistični jezik pesniške univerzalnosti, iščoča pot do sinteze slovenske romantike. V tem smislu sta tudi posnemala formalne oblike, ki so se v zgodovini poezije oblikovale. To sta počela v izrazitem konfliktu s konzervativno strujo, poosebljeno v Jerneju Kopitarju. Ta si je prizadevala za jezik, ki bo lasten vsakemu državljanu: ker je bilo tedaj slovensko ljudstvo pretežno zbor rokodelcev in kmetov, je bil njihov idiom plebejski, popreproščen v izrazu, besedišču in misli, se pravi vse tisto, kar je Prešeren kot drugorazredno označil v zgoraj navedenem nemškem sonetu.

Res je prevladujoče težišče Namečka nemških in ponemčenih poezij (Prešeren: 1960, 68) prav izraz nejevolje zoper Jerneja Kopitarja. To stremi k razkritju njegovih prizadevanj zoper Schleglov tip poezije, nunc pro tunc. A hkrati je Prešeren za Nameček kot uvodni moto celote izbral stavek »getico scripsi sermone libellum «(68), ki ga je vzel iz XIII. enote Pontskih pisem Publija Ovidija Nazona (Ovid: 1959, 213). Stavek sam je delec, kot je v delce razstavljeno, to je nedokončano tudi tovrstno Prešernovo delo v razmerju do spet novih delcev, alias: nedokončanega vprašanja, kateremu jezikovnemu izročilu pesnik sploh pripada, nemškemu ali slovenskemu. ${ }^{8}$ A prav delec je nosilec sintetične celote: zgolj on lahko govori v njenem imenu. To je sicer pomemben element Schleglove estetske šole:

»Iz svoje osebnosti ne morem predstaviti nobenega drugega vzorca kot sistem delca, kajti sam sem prav nekaj podobnega. Noben slog mi ni domač naraven z eno samo izjemo - delcem« (Schlegel: 2004, 221).

7 »Kak stopajo z ošabnimi glavami / ti, ki jim mar ni človeška cena, / kak rad gre v nič najboljši trud med nami. / (Prešeren: 1950, 37).

8 Primerjaj uvodoma, Polejevo klasifikacijo (Polet: 1982, 8). 
Bistveno sporočilo leži v razumevanju delca (navedka) kot takega. Pove, da se je pesnik odločil spregovoriti v jeziku, ki je nižjeroden, barbarski. Subtilne reči sedaj izpoveduje v novoreku neomikanega, divjega in primitivnega ljudstva. Sram ga je, kot je bilo Ovida:
"O saj sram me je, spesnil tu pesem sem v getskem jeziku, /
divji barbarski jaz stih v meri sem naši gradil. /
Njim sem ugajal, čestitaj mi brž, nakar sem med njimi /
divjimi Geti dobil pesnika slavno ime. I
Vprašal boš, kakšno opeval sem snov. Cesarja pač hvalo, /
Dobro, pri delu da tem božjo imel sem pomoč.//.../
Pesmi mi nič ne koristijo, škodile včasih so meni, 9
One tedaj so bile prvi pregnanstva mi vzrok« (Ovid: 1959, 213).

Interpretacija mota, vloženega v celoto Ovidove elegije se ob nekoliko širšem premisleku pokaže v bistveno večji razsežnosti, kot je tista, ki bi se omejevala zgolj na konflikt znotraj dveh literarnih šol. Dosedaj je namreč veljalo: »Vse kakor da je bilo izzvano ali vsaj soizvano od zlobnih Kopitarjevih pripomb k Prešernovim pesmim v rokopisu 4. zvezka Čbelice, kakor da je odgovor na te pripombe: $v$ prvih dveh sonetih kot izraz pesnikove ranjenosti, v zadnjem kot sproščujoč udarec po nasprotniku. Te Kopitarjeve pripombe so bile take, da so, kakor vemo od Čopa, celo pri guberniju zbudile nevoljo. In prav to je po vsej verjethosti bil vzrok (ali vsaj glavni vzrok), da je Prešeren svojemu odgovoru dal nemško obliko: bilo mu je do tega, da ga tam, kjer se je o stvari odločalo, bero in razumejo vsi, tudi tisti, ki nemško niso znali« (Glaser: 1950, 6). Glaserjevo misel je desetletje za tem povzel Anton Slodnjak, pri čemer je obžalovati, da je njeno protislovje še okrepil. Tako:

»S tem je hotel odgovoriti nasprotnikom svojih pesmi, zlasti Kopitarju in podpreti Čopa v njegovem boju z birokratsko-kleriškimi zarotniki zoper slovensko posvetno poezijo. Primerjajoč se z Ovidijem, ki je pisal v pregnanstvu v tujem jezi$k u$, ker ni več mogel misliti na rimske bralce, pa tudi ni mogel molče prenašati trpljenja, je zapisal svoj ciklus v nemškem jeziku« (Slodnjak: 1960, 280).

Prešeren se je primerjal z Ovidom, vendar ne zaradi tega, ker bi ne mogel več misliti na »slovenske bralce«: njim je namreč pisal prej, vmes in pozneje.

Tudi bi bilo nelogično, da bi ob siceršnjem agresivnem tonu, ki ga je uporabljal zoper nasprotnike v tej »vojski«, bežal v tuji jezik in si pri tem za ščit izposojal Ovidov zgled. Protislovnost takšnega sklepanja odkrije že navedeni sonet Zakaj, nji vredni (Prešeren: 1960, 81), kjer se razodenejo stvari, ki posegajo v ontologijo bivanja. S tem pa Kopitar in njegovi več ne morejo biti povezani, kajti v resnici so »škrati«, kot jih pomanjševalno in zaničevalno

9 Prešeren in Čop sta Tiecka dobro poznala, še iz problemov okrog deseterca. 
naziva drugi sonet cikla (Prešeren: 1960, 73). To pravzaprav ugotavlja tudi sam Glaser, ko v zvezi z vsebino gornjega soneta pravi, da je v njem: » z dokumentarno stvarnostjo in jasnostjo formuliral takratni jezikovni (in istočasno politični) položaj na Slovenskem« (Glaser: 1950, 7). Signalu, ki ga izraža takšna besedna oblika, ne pritrjuje samo splošno občutje nemških in ponemčenih pesmi, temveč predvsem središčna formulacijo Venca:

»Bile so v strahu, da boš ti, da zale / slovenke nemško govorit' umetne, / jih bote, ker s Parnasa so očetne / dežele, morebiti zaničvvale« (Prešeren: 1965, 142).

Trditev sodi v red najbolj splošnih, generalnih v etimološkem pomenu besede. Zato je ta položaj razvit v bistvenih meridianih domače in nemške Prešernove govorice, konkretno spet v ključni enoti pričujočega zapisa: »Zakaj, nji vredni« (Prešeren: 1960, 81). Za končno potrditev lahko vzamemo Kidričevo sodbo:

»Prepričal se je (Korytko, op. BMT), da je Prešeren osamljen genij, ki ga mori $v$ središču »Kranjcev« vsa kulturno-literarna mrtvičnost naroda brez narodnosti, nenormalne slovensko-nemške dvoživke, ki je po večini samo nerodno jecljala, kadar je skušala ustvarjati v vtepeni nemščini, a zapravila med vtepanjem tudi stik z rodnim jezikom in ga začela smatrati za neizpremenljivo usodo, da »deutsch sprechen in der Regel hier zu Lande die Herrinen und Herren, die befehlen, slowenisch die, so von dem Dienerstande« (Kidrič: 1978, 128).

Logičen je torej izziv, stvari videti širše, tako pa pojasniti stavo Ovidovega verza kot dejanje izrecne namembnosti. To ne more biti nepovezano s stanjem, kakršnega navaja gornji citat. Naloga je še toliko bolj nujna, ker razen izjeme nihče do sedaj ni poskušal odgovoriti na vprašanje, zakaj je izbran prav tisti del Ovidovega verza, ki govori o barbarskem jeziku. ${ }^{10}$ Ta izjema je Križ nad slovansko Trojo (Marinčič: 2011), ki v prvem poglavju pojasnjuje vprašanje, kateremu se posvečajo tudi te vrstice. Opozoriti je sicer potrebno, da problem vidi v drugačni perspektivi:

»Iz šepave argumentacije se izlušči prepričljivo vtis, da se pred našimi očmi odvija spontano potujčenje enega zadnjh jezikovno zavednih slovenskih piscev. Prepričan sem, da je to mišljeno kot avtoironična ponazoritev, kot didaktična inscenacija asimilacijskega procesa, in da je tudi v tem pogledu Ovidij neposreden zgled. Prvi vzrok za Prě̌ernovo ponemčenje se skriva v namišljenem podoživetju Ovidijieve izkušnje, v fingirani situaciji, ko pesnik pod pritiskom tujega okolja

10 Zanimivo, da se ob tem niso ustavili niti tisti, ki so se izrecno ukvarjali z vprašanjem klasičnih elementov v Prešernovem delu. Npr, Jože Kastelic v inavguralni disertaciji Antični snovni elementi v Prešernovem delu (Kastelic: 1943). Žal dosledne razlage tudi ni najti v sicer izčrpni študiji Kajetana Gantarja, ki se v celoti posveča vprašanju rimskih vplivov na Prešernovo liriko, s posebnim poudarkom na Ovidu (Gantar: 2005). 
čedalje bolj »pozablja« domačo govorico - in nazadnje skoraj spontano spregovori v »barbarskem« jeziku« (Marinčič: 2011, 26-27).

Vendar skriva Križ nad slovansko Trojo formulo, ki pomenljivo sovpada s pričujočo interpretacijo Ovidovega navedka v Prešernovem pesnjenju v nemščini, povezana pa je $\mathrm{z}$ reverzibilnostjo razmerij $\mathrm{v}$ svetu, ki ga vzpostavlja poezija (rimska mila pesem kot njen pars pro toto). Prepričani smo, da Prešeren ni mogel razmišljati dosti drugače.

Citat je torej orodje, katerega učinek bo - kot Exupéryjev aparat ali letalna naprava razodel stvari, o katerih poprej ni bilo mogoče razmišljati. Izstopajoče je, da se inavgurativni del verza v kontekstu, v kakršnega ga Prešeren vlaga, kaže kot sporen. Takšno ovrednotenje večinskega jezika Prešernove domovine namreč ni le v izrecnem nasprotju s siceršnjimi pesnikovimi tezami, iz katerih izhaja pričujoči zapis, temveč predvsem s stvarnostjo. Nemščina ni bila samo po splošnih kriterijih, ki veljajo za kulturnost nekega jezika, pred slovenščino. Stavec citata je celo sam nekatere njene elemente v obliki neposrečenih kalkov iz registra familijarne govorice postavljal na ključna mesta lastne slovenske poezije. ${ }^{11}$ In naprej: v zadnji pesmi cikla Igrala si se (Prešeren: 1960, 115) najdemo še eno programsko misel: gre za verze Ludwiga Tiecka. ${ }^{12}$ Ta je del nemške romantike, ki se spet deli na več sfer. Tieck skupaj z bratoma Schlegel pripada jenski zgodnji romantiki, kot eni njenih pomembnejših variant. A obstajajo še druge, kot obstajajo tudi druga obdobja nemške književnosti. Vendar samo Tieckove zbrane novele (Tieck: 1852 - 1854), ki so sicer ena od tridesetih reči (v smislu literarne zvrsti, pretežno), katere je napisal, vsebujejo številčno več umetnostnih prvin kot vse, kar je bilo do oblikovanja mota $\mathrm{k}$ nemškim in ponemčenim pesmim primerljivega napisano v slovenščini! Če torej upoštevamo diahroni in kvantitativni kriterij števila govorcev in časa, v katerem so ti oblikovali tisto, kar se imenuje kulturno izročilo v nemškem jeziku, je vsakršna sopostavitev nemogoča. Degradirati nemški jezik na mesto barbarskega pa nekaj, kar bi bolj kot na področje literarne teorije sodilo med zidove tiste institucije, ki je po Foucauju nastala šele z novim vekom (Turk: 2014).

A Prešeren je storil prav to, pri čemer je pomemben še en podatek. Vzrok tega, da rimski Ovidij piše v getščini, je najvišji simbol vsekakršne moči na planetu, cesar Avgust. Ta ga je izgnal v Pont in primoral, da je opustil latinščino. Paralela je spet na dlani. Ovid se izraža $v$ barbarščini, zato da bi zadoščeval jezi, zanikanju in krivicam, ki jih je deležen zaradi najmočnejše figure, predstavljajočo linguo franco njegovega imperija. Prešeren uporabi linguo franco monarhije, v kateri živi, da bi s to podobo prišel do vzvoda, s katerim bi najbolj učinkovito zanikal njeno moč in oblast nad lastnim pesnenjem. Pesnik bere Pontska pisma (Ovid: 1959) contra litteram in tako paradoks stopnjuje do končne pregnance.

Da bi to bolje razumeli, moramo k naslednjemu fragmentu, ki se kaže v Zakaj nji vredni (Prešeren: 1965, 81). Tu se težko ponderirane misli, ki temeljijo na neskladju tako s

11 Primerjaj za to mesta v Kidričevi biografiji (Kidrič: 1938, 387).

12 »Nur in Toenen mag sie gern / alles, was sie wiel, verschoenen« (Prešeren: 1960, 115). 
samimi seboj kot s stvarnostjo, razporedijo v občudujoči kalejdoskop raznobežnih pomenov. »Zakaj nji, vredni, da bi vsi jeziki / opevali jo od Homerja dalje, / ker od nobene manj ni po odliki, / kar jih kdaj pesnik poveličeval je« (81) pomeni rangiranje najprestižnejšega objekta pesnikove čudi ${ }^{13}$ na najvišje mesto v svetovnem občestvu vseh, ki so kdaj pomenili kaj velikega na tem področju. Gre za absolutno obliko komplimenta: Julija je tako imenitna, da bi se ji bil moral prikloniti že Homer. »Oznanjam jaz v slovenski le besedi« (81) je paradoks, a s krepkim logičnim jedrom: slovenščina »vskoči« na mesto jezikov, v katerih so se artikulirala najpomembnejša pesniška sporočila, začenši s staro grščino. To pomeni, da se odlikuje tako s težo Homerjevega jezika kot vseh idiomov, v katerih so se izražale podobno sublimne reči. ${ }^{14}$ A poslednja zagonetka šele sledi: kakšno razmerje je sedaj med »gospodo, ki vlada« in govori nemško ter »nji služečim« (81), ki se izražajo v slovenščini, če pa je ta, ki je najvišjih časti vredna, opevana zgolj v slovenščini (in nemščina zanjo ni dovolj): »Oznanjam jaz v slovenski le besedi« (80). ${ }^{15}$ Prešeren si Julije, ki je postala Nemka, ${ }^{16}$ namreč ne želi slaviti v barbarskem jeziku (»getico sermone»), temveč le v njej in njemu lastni materinščini.

Obstaja še en, komplementaren dokaz razmišljanju, ki ga poskuša razviti pričujoči sestavek. To je sonet, ki najbolj govori o tej tematiki, namreč Slovencem, ki pesnijo v nemškem jeziku (101). Tu pričakujemo, da bomo izvedeli največ o stvari: Prešeren na to namreč opozarja s prvim verzom. V resnici pesem pripelje do bistvene paralele, ki tokrat izgnanstvo iz jezika oz. jezikovnega občestva prikaže na boleče krut način, poistoveti ga z izgnanstvom od matere, z večnim desetništvom. »Vi, ki vas kri slovenska je rodila, / ki materi odvzeti, vam omika / rosila ni iz njenega jezika, / ki vas kot mene Nemka je dojila« (101). V tem sonetu je identifikacija z nemščino prignana do najbolj negativne točke. Kaže, kako lucidno in brez sleherne iluzije se je Prešeren zavedal dokončne izgubljenosti vsakogar, ki bi pesnjenje v barbarskem jeziku jemal kot izključno življenjsko opravilo in opustil (hiperbolični) dvom glede tega, kateri jezik je Slovencu izvorno namenjen kot orodje umetelnega besednega sporočanja. In kateri bi bil njegov približni povzetek.

Prešeren pa bi naloge ne opravil do kraja, če bi tudi tega tipa opravila ne postavil v paradigmo romantičnega razmerja med delcem in celoto. Spozabi pesnjenja v nemškem jeziku resda oporeka na najbolj ultimativen način, a pod pogojem, da avtor zagreši celostno pozabo matere oz. materinščine. V kolikor pa gre za enkraten akt, ki celote ne osmišljuje, pa bodi tudi pesnjenje v barbarskem jeziku ustrezno optimalim kriterijem. V tem je presenetljivo podoben Ovidu, ki se mu kot posledica »getico scripsi sermone libellum « zgodilo to, da je postal »barbarski« lavreat«: »Meni ljubezen je ljudstva ovenčala z lovorom glavo, / tukaj, čeprav nerad, ljudsko to čast sem prejel« (Ovid 1959, 216). S tega stališča ne

13 Gre za Julijo. Primerjaj: »Prešeren je zložil sonet v odgovor tistim znancem v ljubljanski meščanski družbi, ki so ga spraševali, zakaj ne opeva Julije v nemškem jeziku« (Prešeren: 1960, 284)

14 Začenši tu z italijanščino, z Beatrice in Lavro.

15 Izvirnik je tu neizprosen: le, to je »nur«»Vom mir nur in der Sprache der Slowenen« (Prešeren: 1965, 80).

16 To pomeni govoreča ta jezik ter priznavajoča njegov celoviti primat. 
preseneča, da Prešeren terja kar najvišjo kvalitativno stopnjo v pisanju verzov, če se je že kdo lotil te naloge:

»Naj pravi materi pravic ne krati, / rejencu pa spodobi se, seveda, / da za spomin rednici kaj odrine. / Od žlahnte rude, ne navadne gline, / pa bodi, kar daruje prebogati, / ki na beraštvo le z zasmehom gleda« (Prešeren: 1960, 101).

Razlog je univerzalen in je na dlani: najbolj silovito razmerje med antinomijami, ki se jim tu posvečamo, se odkriva v posthumni zgodbi človeka, brez katerega bi tudi Franceta Prešerna ne bilo ali pa bil bil drugačen. Imenujemo jo elegija Spominu Matije Čopa (Prešeren: 1960, 91), pomeni pa poseg tokrat ne več zgolj v pesniško materijo romantizma, temveč v njegove onto-filozofske predpostavke, kjer se gibanje staplja s tistim, kar se imenuje večni duh. Analiza te mojstrovine v luči nemškega idealizma z interpretacijo ključnega vprašanja, kaj je moč iz tega sklepati glede celotne Prešernove lirike, je nujna naloga. Kam naj gre smer raziskave, se že odčrtuje iz zaključka pričujočega sestavka. Eno k drugemu: mila pesem je spisana v barbarskem jeziku, in to tako mojstrsko, da se je ne bi sramovali največji ustvarjalci, posvečeni v njegov »genij«.

Če so pesmi »pregnastva vzrok«, je to lahko različnih narav, še posebej pri pesništvu »Svet rimske ljubezenske elegije je skoraj v vsem obratna slika razmerij v rimski družbi« (Marinčič: 2011, 35). To je Prešeren moral vedeti: dalo mu je moči za obrat, v katerem je nemški jezik definiral kot barbarski, opirajoč se na Ovidovo gesto. »Getico scripsi« je glede na filozofsko podstat gibanja pravzprav nujna premisa, obstoječa v epifenomenološkem zapopadku avtorja, ne glede na materialno, pojavno in duhovno predmetnost. Romantika je rojena s pojmom moderne subjektivitete: slednjo dolgujemo Kritiki čistega uma Immanuela Kanta (Immanuel Kant 2001). Stvari same na sebi ne moremo spoznati. A bistven ni predmet spoznanja, temveč spoznavajoči subjekt. To je kolosalna revolucija v gnoseologiji, imenujemo jo Kantov kopernikanski preobrat. Ne določa predmet zavesti, temveč določa zavest predmet. Tako:

»Res je: prizadevamo si verjeti, da je vsako spoznanje, ki naj bo resnično, nujno poravnano s predmeti le-tega. To prepričanje je tako trdno ukoreninjeno, da na nas vpliva brez naše volje ali izrecne privolitve: čisto enako se je dogajalo z onim, katerega oče je bil Ptolomej, predvidevalo pa je, da se vse zvezde gibljejo okrog negibnega opazovalca na Zemlji. Ampak prav Kopernikova hipoteza, ki je predpostavila obratno, je omogočila ključen preboj v astronomskih spoznanjih. Zato nam nudi opogumljajoč zgled. Predpostavljajoč, da so predmeti spoznave tisti, ki se ravnajo po spoznanju samem, bomo lahko pojasnili, kako je slednje mogoče a priori, to je upoštevaje pravila in predpise, ki jih moč razuma izvaja iz sebe same, ne oziraje se na zaznavno izkušnjo. Tako je moč odnos spoznavanja do predmeta spoznave razložiti a priori, najsi gre bodisi za neposredno 
spoznavo, kot jo zagotavlja intuicija, bodisi spet za posredno spoznavo, do katere se razum prebija preko razločevalnih elementov, kot jih prepoznava presodna moč človeškega duha. Nič več se ne bo zdelo nepogrešljivo, če predmet spoznave ne bo dan s pomočjo čutne zaznave, da bi se spoznanje lahko poravnalo z njim. Nasprotno: svet materialne pojmovne ali duhovne predmetnosti (objectivité) bo od sedaj naprej odvisen od pogojev, ki jih postavlja spoznavajoči subjekt (sujet qui connaît)« (Guillermit: 1998, 817). ${ }^{17}$

Kantov gnoseološki preobrat, konkretno filozofska interpretacija Louisa Guillermita, omogočajo preformulirati Ovidov citat v luči moderne subjektivitete. Ta si je materialno, pojmovno ali duhovno predmetnost ljubljenca »Kamen rimljanskih« (Prešeren: 1960, 69) ob Pontu zamislila drugače, kot bi se to večini človeštva zdelo na prvi pogled. Iz ptolomejskega je v najbolj nemogočih razmerah zaostale provincialne gubernije nastal kopernikanski človek, ki je fiktivno središče (nemštvo) zamenjal za dejansko (slovensko). S tem je v majhni skupini ljudi na evropskem obrobju zasedel mesto lirika s težo, kakršno sicer poznamo v zvezi z velikimi imeni literarne zgodovine starega sveta.

To je tudi razlog, da Prešeren Namečka nemških in ponemčenih poezij ni hotel vključiti v Poezije (Prešeren: 1847). Kako pa bi barbarski jezik lahko bil del literarnega kanona?

\section{LITERATURA}

ALYN, Marc (1982) France Prě̌eren, poète slovène, Paris: Actuelles formes et langages. GUERNE, Armel (2004) Les Romantiques allemands. Paris: Phébus.

GUILLERMIT, Louis (1998) Kant Emmanuel. J. Greisch (ur.), Philosophes. Paris: Albin Michel, 811-832.

ILEŠIČ, Fran (1900) Prešeren in slovanstvo. Ljubljana: Schwenter.

KANT, Immanuel (2001) Kritika čistega uma. Ljubljana: Annalecta.

KASTELIC, Jože (1943) Antični snovni elementi v Prě̌ernovem delu. Ljubljana: Inštitut za slovansko filologijo.

KIDRIČ, France (1938) France Prešeren, I, II. Ljubljana: Tiskovna zadruga.

KIDRIČ, France (1978) Izbrani spisi II. Ljubljana: SAZU.

MARINČIČ, Marko (2011) Križ nad slovansko Trojo. Ljubljana: Matica.

MODER, Janko (1995) Prě̌ernove nemške. Ljubljana: Karantanija.

OVIDIJ, Publij Nazon (1959) Pisma iz pregnanstva. Ljubljana, Državna založba Slovenije. OVIDIUS, Nason (1965) Tristia, Ex Ponto. London: William Heinemann.

PEYRE, Henri (1971) Qu'est ce que c'est le Romantisme. Paris: PUF.

POLET, Jean-Claude (1999) Patrimoine Littéraire européen, Paris, Bruxelles: De Boeck Université.

17 Besedila je iz francoskih izvirnikov prevedel avtor pričujočega članka. 
PREŠEREN, France (1950) Nemške poezije. J. Glaser (ur). Ljubljana: SAZU.

PREŠEREN, France (1960) Pesmi in pisma II. A. Slodnjak (ur). Ljubljana: Mladinska knji-

ga.

PREŠEREN, France (1965) Zbrano delo I. Ljubljana: Državna založba Slovenije.

PREŠEREN, France (1966) Zbrano delo II. Ljubljana: Državna založba Slovenije.

SAUSSURE, Ferdinand de (1998) Predavanja iz splošnega jezikoslovja. Ljubljana: Studia Humanitatis.

STRITAR, Josip (1955) Zbrano delo VI. Ljubljana: Državna založba Slovenije. TIECK, Ludwig (1852-1854) Gesammelte Novellen I - XII. Berlin: Reimer.

TURK, Boštjan, M. (2014). L'Ascendant du doute hyperbolique sur le protoprologue des grandes tragédies cornéliennes. Acta neophilologica 47, 109-120.

\section{POVZETEK}

\section{Niz Prešernovih jezikov}

Članek se posveča analizi uvodnega mota v Nameček nemških in ponemčenih poezij »getico scripsi sermone libellum«, ki jih je France Prešeren sprva namenil za objavo skupaj s Poezijami, kasneje pa jih je pustil zunaj zbirke. Članek ugotavlja, da je razlog opustitve v razmerju med linguo franco Avstro-ogrske monarhije in slovenščino. Prešeren je moto izbral namenoma, da bi svoje pisanje v nemščini identificiral s položajem Ovida, ko se znajde v pontskem izgnanstvu in začne pisati v barbarskem jeziku. Prešernova kretnja, s katero nemščino označi za barbarski jezik, najde svojo utemeljitev v romantični filozofiji modernega subjektivizma, ki temelji na Kantovem gnoseološkem obratu. Ne določa svet zavesti, temveč določa zavest svet. Zgolj v luči te sodbe a priori je bilo Francetu Prešernu mogoče zavzeti takšno stališče, na ta način pa protestirati zoper splošno prakso zatiranja njegove materinščine. Z oznako nemških poezij s slabšalnim izrazom »nameček« in s končno opustitvijo lastnih besedil, je ta filozofski nazor tudi potrdil na lastnem zgledu.

Ključne besede: France Prešeren, Ovid, romantika, nemščina, Kantov kopernikanski obrat

\section{ABSTRACT}

\section{A String of Prešeren's Languages}

The article deals with the part of Prešeren's poetic work written in German, the obvious lingua fran$c a$ of the Austro-Hungarian empire. The poet, in spite of good intentions to do so, never published these poems as a whole. He chose a motto from Ovid's Ex Ponto instead: "getico scripsi sermone libellum «, which reads: »I wrote a book in a barbaric language«. The article tries to find out the reason for identifying German as barbaric. The answer may lie in a particular romantic attitude towards reality, explained by Immanuel Kant. He established the »Copernican turn« in the behaviour of the human knowledge and consciousness. It is the innate structures of the mind that determine the nature of experience. According to him, only through an account of the a-priori principles of the mind can 
knowledge be validated and objective, and thus lead to reality. This is the path to the modern subjectivity. Prešeren as a romantic poet profoundly integrated Kant's vision in his poetry protesting thus against the predominant German culture of the time.

Key words: France Prešeren, Ovidius, romanticism, German language, Kant's »Copernicus reversal« 